\title{
Hubungan Antara Kondisi Rumah Susun Dengan Kepuasan TingGal Penghuni Di Kota Surakarta
}

\author{
Anis Yuniarta, Winny Astuti, Galing Yudana \\ Program Studi Perencanaan Wilayah dan Kota, \\ Jurusan Arsitektur, Fakultas Teknik \\ Universitas Sebelas Maret, Surakarta \\ email: anis.yuniarta@gmail.com
}

\begin{abstract}
Flats built as one of the alternative solutions to problems of land acquisition which is very hard to come by. There are limitations in the management of flats in Surakarta, then the resulting problems related to the condition of flats. The research problem is how to relation between condition of flats with stay occupants satisfaction in Surakarta. The method of this study is to conduct a survey of condition of flats and make the distribution of questionnaires to residents. The analysis was performed with the scoring technique and correlation analysis. Based on the analysis, found that condition of flats which has a positive correlation to the satisfaction of the inhabitants stay the distance to shopping facilities, distance to health facilities, pollution-free, the physical condition of the road and pedestrian, access to clean water, and environmental facilities. Flats for conditions that have a negative correlation to the satisfaction of the inhabitants live the ease of transportation, distance to education, distance to services and banking, distance to government services, access to the waste water, and access to electricity.
\end{abstract}

Keywords: Relation, Stay Satisfaction, Condition of Flats, Occupants, Flats

\section{PENDAHULUAN}

Rumah susun adalah bangunan gedung bertingkat yang dibangun dalam suatu lingkungan yang terbagi dalam bagianbagian yang distrukturkan secara fungsional, baik dalam arah horizontal maupun vertikal. (UU RI No. 20 Tahun 2011). Rumah susun merupakan alternatif pilihan perumahan di kota akibat keterbatasan dan harga lahan yang mahal (Komarudin, 1997). Rumah susun dibangun sebagai upaya pemerintah guna memenuhi masyarakat perkotaan akan papan yang layak dalam lingkungan yang sehat. Selain itu, hal ini juga dijadikan sebagai salah satu alternatif pemecahan masalah pengadaan lahan yang sangat sulit didapat. Pembangunan rumah susun dapat menjadi solusi bagi penataan kawasan kumuh di perkotaan. Di samping itu, pembangunan rumah susun juga akan membantu mengatasi kemacetan lalu lintas dan dapat menekan serta menghemat biaya transportasi. Pembangunan rumah susun khususnya ditujukan pada golongan masyarakat berpenghasilan rendah.

Pembangunan rumah susun menjadi alternatif Pemerintah Kota Surakarta untuk memenuhi kebutuhan hunian masyarakatnya terutama bagi masyarakat berpenghasilan rendah. Pemerintah Kota Surakarta berencana membangun dua belas rumah susun dan lima diantaranya sudah teralisasi. Namun, empat rumah susun yang sudah beroperasi. Keempat rumah susun tersebut Rumah Susun Sewa Semanggi, Rumah Susun Sewa Begalon dan Rumah Susun Sewa Jurug, dan Rumah Susun Sewa Kerkop. Rumah Susun Sewa Kerkop baru beroperasi pada Desember 2013 sehingga banyak unit rumah susun yang belum dihuni.

Kepuasan tinggal penghuni menurut Wadiastomo dan Yuliastuti (2013) adalah sebuah konsep untuk mengevaluasi perasaan penghuni tentang kondisi tempat tinggal mereka. Ada beberapa hal yang menyakut masalah kondisi rumah susun yang berhubungan dengan kepuasan tinggal penghuni rumah susun diantaranya adalah masalah fisik kondisi rumah susun. Berdasarkan permasalahan tersebut dapat diketahui bahwa kondisi rumah susun mempengaruhi kepuasan tinggal penguninya. Karena tingkat kepuasan dapat digunakan untuk mengevaluasi perasaan terhadap kondisi rumah susun. 
Tujuan dari penelitian ini adalah mengetahui hubungan antara kondisi rumah susun dengan kepuasan tinggal penghuni rumah susun di Kota Surakarta.

\section{METODE}

\subsection{Ruang Lingkup}

Di Kota Surakarta ada beberapa rumah susun diantaranya Rumah Susun Sewa Semanggi, Rumah Susun Sewa Begalon, Rumah Susun Sewa Jurug, dan Rumah Susun Sewa Kerkop. Namun, untuk ruang lingkup wilayah yang akan dicapai dalam penelitian ini adalah lokasi rumah susun di Kota Surakarta meliputi Rumah Susun Sewa Semanggi, Rumah Susun Sewa Begalon, dan Rumah Susun Sewa Jurug. Rumah Susun Sewa Begalon mulai dihuni tahap I tahun 2004, kemudian tahap II tahun 2009, untuk Rumah Susun Sewa Semanggi dihuni pada tahun 2008 dan 2009 secara bertahap. Sedangkan Rumah Susun Sewa Jurug mulai dihuni tahun 2010 dan 2011 secara bertahap. Namun, untuk Rumah Susun Sewa Kerkop tidak masuk dalam ruang lingkup studi karena Rumah Susun Sewa Kerkop baru mulai dihuni bulan Desember 2013 dan masih belum lengkap penghuninya. Ketiga lokasi rumah susun tersebut dapat dilihat pada lampiran peta.

\subsection{Metode Analisis}

Penelitian ini menggunakan metode analisis korelasi dengan bantuan SPSS 21 . Analisis korelasi digunakan untuk mengetahui ukuran kekuatan atau kekuatan hubungan antara dua variabel. Koefisien korelasi mengukur kekuatan hubungan tersebut. Analisis korelasi adalah metode statististik yang digunakan untuk mengukur besarnya hubungan antara dua variabel. Nilai koefisien korelasi berkisar antara -1 hingga 1, di mana nilai korelasi -1 berarti hubungan antara dua variabel tersebut adalah hubungan negatif sempurna, nilai korelasi 0 berarti tidak ada hubungan antara dua variabel tersebut, sedangkan nilai korelasi 1 berarti terdapat hubungan positif sempurna antara dua variabel tersebut (Yamin, 2009). Interpretasi dari besarnya nilai korelasi antara variabel dapat diklasifikasikan sebagai Tabel 1 berikut :
Tabel 1 Pedoman untuk Memberikan

Interpretasi Koefisien Korelasi

\begin{tabular}{|c|c|c|}
\hline $\begin{array}{l}\text { Interval } \\
\text { Koefisien } \\
\text { Korelasi }\end{array}$ & $\begin{array}{c}\text { Tingkat } \\
\text { Hubungan }\end{array}$ & $\begin{array}{c}\text { Hasil } \\
\text { Hubungan }\end{array}$ \\
\hline $0,00-0,199$ & $\begin{array}{l}\text { Sangat } \\
\text { Rendah }\end{array}$ & \multirow{5}{*}{$\begin{array}{c}\text { Tanda (-) } \\
\text { berarti } \\
\text { negatif dan } \\
\text { tidak } \\
\text { memiliki } \\
\text { tanda berarti } \\
\text { positif }\end{array}$} \\
\hline $0,20-0,399$ & Rendah & \\
\hline $0,40-0,599$ & Sedang & \\
\hline $0,60-0,799$ & Kuat & \\
\hline $0,80-1,000$ & Sangat Kuat & \\
\hline
\end{tabular}

\section{HASIL DAN PEMBAHASAN}

3.1 Identifikasi Kondisi Rumah Susun di

\section{Kota Surakarta}

Untuk mengidentifikasi kondisi rumah susun di Kota Surakarta dengan cara skoring berdasarkan standar skoring dengan kriteria indikator yang telah ditentukan. Dari hasil tersebut kemudian dilakukan perhitungan nilai skoring yang selanjutnya ditentukan kriteria atas hasil nilai skoring yang telah diperoleh dengan kriteria sangat buruk, buruk, cukup baik, baik, dan sangat baik. Adapun hasilnya dapat dilihat pada Lampiran Tabel 1.

Dari Tabel 1 diketahui bahwa kondisi rumah susun di Kota Surakarta yang memiliki kriteria cukup baik yaitu tentang kemudahan transportasi (3.4), jarak ke sarana kesehatan (3.4), jarak ke jasa dan perbankan (3.1), kondisi fisik jalan dan pedestrian (3.1). Sedangkan yang memiliki kriteria baik yaitu fasilitas lingkungan (4.1), akses terhadap listrik (4.0), jarak ke pelayanan pemerintahan (3.9), jarak ke sarana pendidikan (3.8), akses terhadap air limbah (3.7), bebas polusi udara, polusi suara, dan polusi air (3.6), jarak ke sarana perbelanjaan (3.5), akses terhadap air bersih (3.5).

\subsection{Identifikasi Kepuasan Tinggal Penghuni Rumah Susun di Kota Surakarta}

Untuk mengidentifikasi kepuasan tinggal rumah susun di Kota Surakarta dengan cara skoring berdasarkan standar skoring dengan kriteria indikator yang telah ditentukan. Dari hasil tersebut kemudian dilakukan perhitungan nilai skoring yang selanjutnya ditentukan kriteria atas hasil 
nilai skoring yang telah diperoleh dengan kriteria sangat tidak puas, tidak puas, cukup puas, puas, sangat puas. Adapun hasilnya dapat dilihat pada Lampiran Tabel 2.

Dari Tabel 2 diketahui bahwa kepuasan tinggal penghuni rumah susun di Kota Surakarta yang memiliki kriteria puas yaitu fasilitas lingkungan (4.2), jarak ke pelayanan pemerintahan (3.9), bebas polusi udara, polusi suara, dan polusi air (3.8), kondisi fisik jalan dan pedestrian (3.8), akses terhadap air limbah (3.8), jarak ke sarana kesehatan (3.7), akses terhadap listrik (3.7), kemudahan transportasi (3.6). Sedangkan yang memiliki kriteria cukup puas yaitu jarak ke sarana pendidikan (3.4), jarak ke sarana perbelanjaan (3.3), jarak ke jasa dan perbankan (3.3).

\subsection{Analisis Hubungan antara Kondisi Rumah Susun dengan Kepuasan Tinggal Penghuni di Kota Surakarta}

Ada tidaknya hubungan antara kondisi rumah susun dengan kepuasan tinggal penghuni dapat ditunjukkan dengan tanda negatif maupun tanda positif. Sedangkan tingkat hubungannya ditunjukkan dengan kriteria rendah dan sangat rendah. Nilai nilai hubungan tersebut dapat dilihat pada Lampiran Tabel 3.

Dari hasil analisis diketahui bahwa yang memperoleh tingkat hubungan sangat rendah adalah kemudahan transportasi, jarak ke sarana perbelanjaan, jarak ke sarana pendidikan, jarak ke jasa dan perbankan, jarak ke sarana kesehatan, jarak ke pelayanan pemerintahan, bebas polusi, kondisi fisik jalan dan pedestrian, akses terhadap air limbah, akses terhadap listrik, dan fasilitas lingkungan. Sedangkan yang memperoleh tingkat hubungan rendah adalah akses terhadap air limbah.

\section{KESIMPULAN}

Hubungan antara kondisi rumah susun dengan kepuasan tinggal penghuni di Kota Surakarta adalah sebagai berikut:

1. Kondisi rumah susun yang mempunyai hubungan positif terhadap kepuasan tinggal penghuni adalah:

a. Jarak ke sarana perbelanjaan

Sarana perbelanjaan yang dekat dengan rumah susun memudahkan penghuni untuk membeli barang kebutuhan seharihari sehingga penghuni merasa puas akan jarak menuju sarana perbelanjaan.

b. Jarak ke sarana kesehatan

Sarana kesehatan yang dekat dengan rumah susun memudahkan penghuni untuk cepat mendapatkan pertolongan bagi penghuni yang sakit sehingga penghuni merasa puas akan jarak menuju sarana kesehatan.

c. Bebas polusi

Lokasi rumah susun yang bebas dari polusi membuat nyaman untuk tinggal sehingga penghuni merasa puas akan lokasi rumah susun.

d. Kondisi fisik jalan dan pedestrian Dengan kondisi jalan yang tidak bergelombang membuat penghuni merasa puas.

e. Akses terhadap air bersih Keberadaan air bersih yang layak konsumsi maka penghuni merasa puas.

f. Fasilitas lingkungan

Fasilitas lingkungan yang lengkap membuat penghuni merasa puas.

2. Kondisi rumah susun yang mempunyai hubungan negatif terhadap kepuasan tinggal penghuni adalah:

a. Kemudahan transportasi

Keberadaan alat transportasi publik di Kota Surakarta tidak memiliki hubungan dengan kepuasan tinggal penghuni karena sebagian besar penghuni memiliki motor.

b. Jarak ke sarana pendidikan Jarak menuju sarana pendidikan tidak memiki hubungan dengan kepuasan tinggal penghuni karena penghuni lebih memilih pendidikan yang baik dan terjangkau walaupun jaraknya jauh.

c. Jarak ke jasa dan perbankan Jarak menuju sarana jasa dan perbankan tidak memiliki hubungan dengan kepuasan tinggal penghuni karena sebagian besar penghuni rumah susun berpenghasilan rendah dan penghuni tidak menabung uang di bank.

d. Jarak ke pelayanan pemerintahan Jarak menuju pelayanan pemerintahan tidak memiliki hubungan terhadap kepuasan tinggal penghuni rumah susun akan jarak pelayanan pemerintahannya. 
Tetapi penghuni lebih merasa puas akan kemudahan pelayanannya.

e. Akses terhadap air limbah

Akses terhadap air limbah tidak memiliki hubungan pada kepuasan tinggal penghuninya. Namun, penghuni rumah susun tidak merasa puas akan pengelolaan air limbahnya. Di Rusunawa Semanggi dan Rusunawa Begalon kurangnya menjaga kebersihan akan saluran buangan / air limbah. Sehingga saluran tersebut mampet dan menimbukan bau yang tak sedap.

f. Akes terhadap listrik

Akses terhadap listrik tidak memiliki hubungan pada kepuasan tinggal penghuninya. Penghuni merasa puas akan listrik bukan karena besarnya tegangan listrik yang didapatkan. Melainkan penghuni merasa puas jika aliran listrik untuk memenuhi kebutuhan sehari-hari lancar tidak mati listrik setiap saat.

\section{REFERENSI}

UU RI No. 20 Tahun 2011 tentang Rumah Susun

Komarudin. 1997, Menelusuri Pembangunan Perumahan dan Permukiman, Jakarta, Rakasindo.

Widiastomo Yudhi dan Nany Yuliastuti, 2013, Kajian Kepuasan Penghuni Berdasarkan Kualitas Lingkungan di Perumnas Bukut Sendangmulyo Semarang, Teknik Perencanaan Wilayah dan Kota, Undip.

Yamin, Sofyan. 2009, SPSS Complete Teknik Analisis Statistik terlengkap dengan Software SPSS, Penerbit Salemba Infotek.

Sugiyono. 2008. Metode Penelitian Kuantitatif Kualitatif dan $R \& D$, Alfabeta. 


\section{LAMPIRAN}

Tabel 1. Hasil Nilai Skoring dan Kriteria Kondisi Rumah Susun di Kota Surakarta

\begin{tabular}{|l|c|c|}
\hline \multicolumn{1}{|c|}{ Kondisi rumah susun } & Nilai Skoring & Kriteria \\
\hline Lokasi & & Cukup Baik \\
\hline Kemudahan transportasi & 3.4 & Baik \\
\hline Jarak ke sarana perbelanjaan & 3.5 & Baik \\
\hline Jarak ke sarana pendidikan & 3.8 & Cukup Baik \\
\hline Jarak ke jasa dan perbankan & 3.1 & Cukup Baik \\
\hline Jarak ke sarana kesehatan & 3.4 & Baik \\
\hline $\begin{array}{l}\text { Jarak ke pelayanan pemerintahan (kantor RT, } \\
\text { Gedung Serbaguna, poskamling) }\end{array}$ & 3.9 & Baik \\
\hline Bebas polusi udara, polusi suara, dan polusi air & 3.6 & Cukup Baik \\
\hline Karakter Fisik Lingkungan & & Baik \\
\hline Kondisi fisik jalan dan pedestian & 3.1 & Baik \\
\hline Prasarana Lingkungan & & Baik \\
\hline Akses terhadap air limbah & 3.7 & Baik \\
\hline Akses terhadap air bersih & 3.5 & \\
\hline Akses terhadap listrik & 4.0 & \\
\hline Fasilitas lingkungan & 4.1 & \\
\hline Fasilitas lingkungan & & \\
\hline
\end{tabular}

Tabel 2. Hasil Nilai Skoring dan Kriteria Kepuasan Tinggal Penghuni Rumah Susun di Kota Surakarta

\begin{tabular}{|l|c|c|}
\hline \multicolumn{1}{|c|}{ Kondisi rumah susun } & Nilai Skoring & Kriteria \\
\hline Lokasi & & Puas \\
\hline Kemudahan transportasi & 3.6 & Cukup Puas \\
\hline Jarak ke sarana perbelanjaan & 3.3 & Cukup Puas \\
\hline Jarak ke sarana pendidikan & 3.4 & Cukup Puas \\
\hline Jarak ke jasa dan perbankan & 3.3 & Puas \\
\hline Jarak ke sarana kesehatan & 3.7 & Puas \\
\hline $\begin{array}{l}\text { Jarak ke pelayanan pemerintahan (kantor RT, } \\
\text { Gedung Serbaguna, poskamling) }\end{array}$ & 3.9 & Puas \\
\hline Bebas polusi udara, polusi suara, dan polusi air & 3.8 & Puas \\
\hline Karakter Fisik Lingkungan & & Puas \\
\hline Kondisi fisik jalan dan pedestian & 3.8 & Cukup Puas \\
\hline Prasarana Lingkungan & & Puas \\
\hline Akses terhadap air limbah & 3.8 & Puas \\
\hline Akses terhadap air bersih & 3.3 & \\
\hline Akses terhadap listrik & 3.7 & \\
\hline Fasilitas lingkungan & 4.2 & \\
\hline Fasilitas lingkungan & & \\
\hline
\end{tabular}


Tabel 3. Hubungan antara Kondisi Rumah Susun dengan Kepuasan Tinggal Penghuni di Kota Surakarta

\begin{tabular}{|c|c|c|c|}
\hline $\begin{array}{c}\text { Hubungan Antara Kondisi } \\
\text { Rumah Susun dengan Kepuasan } \\
\text { Tinggal Penghuni Rumah Susun } \\
\text { di Kota Surakarta } \\
\end{array}$ & Nilai Korelasi & $\begin{array}{c}\text { Tingkat } \\
\text { Hubungan }\end{array}$ & Hasil Hubungan \\
\hline Kemudahan Transportasi & $-0,038$ & Sangat Rendah & Negatif \\
\hline Jarak ke Sarana Perbelanjaan & 0,028 & Sangat Rendah & Positif \\
\hline Jarak ke Sarana Pendidikan & $-0,019$ & Sangat Rendah & Negatif \\
\hline Jarak ke Jasa dan Perbankan & $-0,038$ & Sangat Rendah & Negatif \\
\hline Jarak ke Sarana Kesehatan & 0.190 & Sangat Rendah & Positif \\
\hline Jarak ke Pelayanan Pemerintahan & $-0,086$ & Sangat Rendah & Negatif \\
\hline Bebas Polusi & 0,084 & Sangat Rendah & Positif \\
\hline Kondisi Fisik Jalan dan Pedestrian & 0,003 & Sangat Rendah & Positif \\
\hline Akses terhadap Air Limbah & $-0,026$ & Sangat Rendah & Negatif \\
\hline Akses terhadap Air Bersih & 0.356 & Rendah & Positif \\
\hline Akses terhadap Listrik & $-0,043$ & Sangat Rendah & Negatif \\
\hline Fasilitas Lingkungan & 0,099 & Sangat Rendah & Positif \\
\hline
\end{tabular}




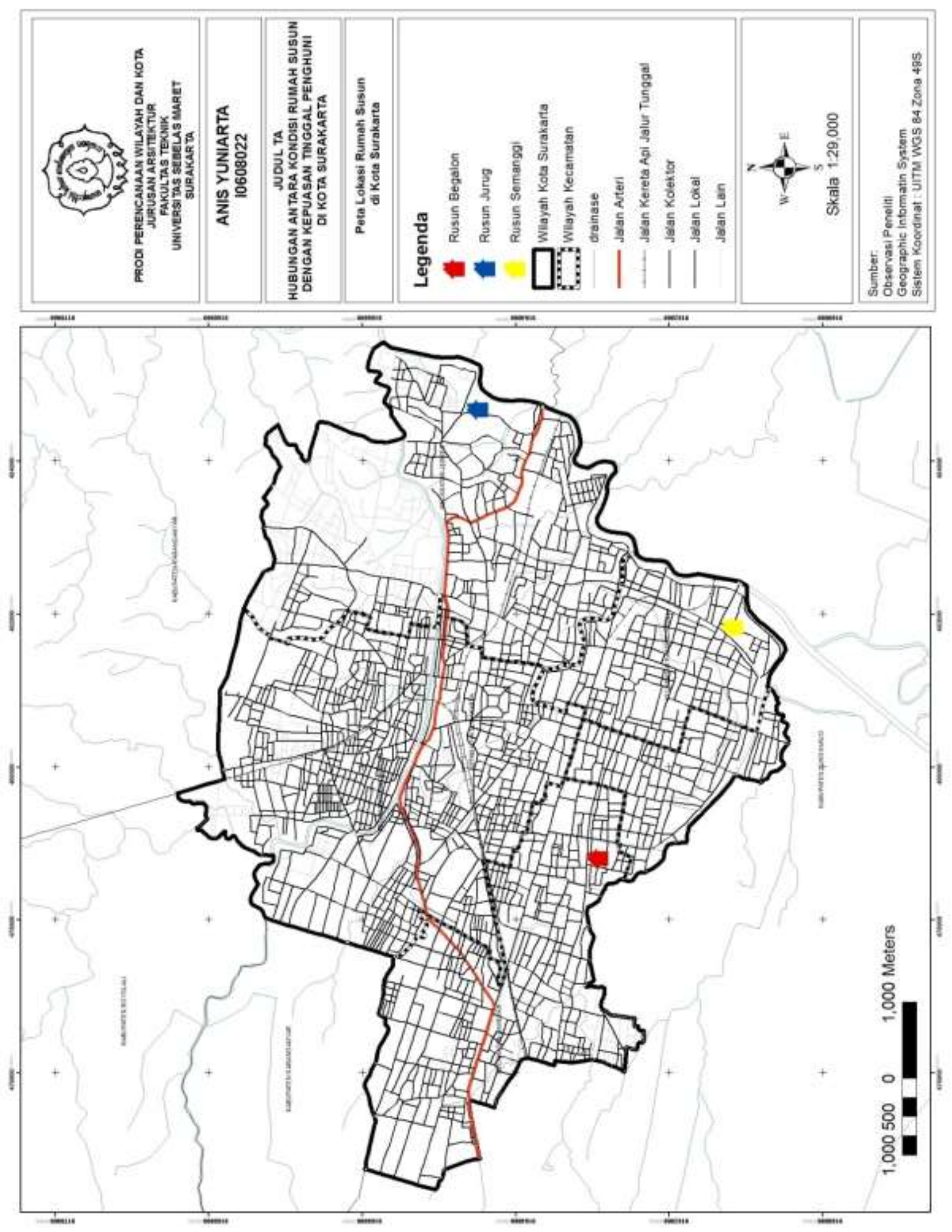

